\title{
Quantum Chemical Study of Spin Transitions in the Bimetallic Fe/Co Complexes with the Bis(catecholate) Bridging Ligand
}

\author{
M. G. Chegerev ${ }^{a}$ * , A. G. Starikov ${ }^{a}$, and A. A. Starikova ${ }^{a}$ \\ a Institute of Physical and Organic Chemistry, Southern Federal University, Rostov-on-Don, Russia \\ *e-mail: mchegerev@sfedu.ru \\ Received February 16, 2021; revised February 25, 2021; accepted March 1, 2021
}

\begin{abstract}
The computational modeling of the spatial and electronic structures, energy characteristics, and magnetic properties of the bimetallic iron and cobalt complexes with 9,10-dimethyl-9,10-ethano-9,10-dihydro-2,3,6,7-tetrahydroxyanthracene and terminal tris(2-pyridylmethyl)amine bases is performed using the density functional theory method (DFT UTPSSh/6-311++G(d,p)). The chosen tetradentate redox ligand is shown to be a promising precursor for the production of magnetically active compounds. The calculations make it possible to establish a relationship between the relative energies of the electronic isomers of the complexes and the structures of the ancillary N-donor moieties. The coordination compounds prone to the manifestation of spin transitions accompanied by a change in the magnetic properties are revealed.
\end{abstract}

Keywords: iron, cobalt, tris(2-pyridylmethyl)amine, redox-active ligand, quantum chemical calculations DOI: $10.1134 / \mathrm{S} 1070328421090013$

\section{INTRODUCTION}

Coordination compounds of metals with redoxactive ligands attract increasing interest of chemists and materials scientists due to their potential use as a basis for devices of molecular electronics and spintronics [1-10]. If the structural components are chosen rationally, these molecules can exhibit reversible mutual transformations between electronic isomers (electromers [11]) with various magnetic properties. The polystable compounds that can be switched between three and more electromeric forms [12-19] are of special interest, since they can be used in storage systems of high-density data or for performing complicated logical operations.

Spin crossover (SCO) $[20,21]$ caused by the rearrangement of electrons inside the valence shell of the coordinated metal ion and redox isomerism (or valence tautomerism (VT) [22-24], i.e., intramolecular electron transfer between the metal center and redox-active ligand) are among the widely studied mechanisms of switching spin states of complexes. The $\mathrm{SCO}$ is most frequently met in the iron complexes in the $\mathrm{N}_{6}$ or $\mathrm{N}_{4} \mathrm{O}_{2}$ coordination environment $[25,26]$ and is accompanied by transitions of the metal ion between the low-spin (LS) and high-spin (HS) states. In turn, the transformation of the LS electromer containing ${ }_{\mathrm{LS}} \mathrm{Co}^{\mathrm{III}}$ and the dianionic catecholate (Cat) form of the redox ligand into the $\mathrm{HS}$ isomer ${ }_{\mathrm{HS}} \mathrm{Co}^{\mathrm{II}} \mathrm{SQ}$ (SQ is the radical-anion semiquinone form of $o$-benzoquinone) occurs in the VT systems, the classical examples of which are the cobalt $o$-benzoquinone complexes $[8$,
$22,27,28]$. The binuclear metal complexes demonstrate partial, one- or two-step SCO/VT rearrangements [14].

An abundant type of coordination compounds with redox ligands is presented by the salt-like metal complexes containing the $o$-benzoquinone derivative and ancillary tetradentate nitrogen-containing bases [2937]. According to the theoretical [29, 38-42] and experimental [30-37] data, thus constructed monoand binuclear systems are capable of exhibiting spin transitions due to the VT and/or SCO. It is found that the possibility of rearrangements leading to a change in the magnetic properties and their character are determined by the nature of the metal center $(\mathrm{Fe} / \mathrm{Co})$, structure of the redox-active ligand, and type of the nitrogen-containing base.

9,10-Dimethyl-9,10-ethano-9,10-dihydro-2,3,6,7tetrahydroxyanthracene $(\mathrm{L})$ is the synthetically available but poorly studied bis(catecholate) ligand. The octauranate cage complexes [43] and manganese(III) [44] and platinum(II) [45] compounds based on ligand $\mathrm{L}$ are known. The possibility of the two-step VT accompanied by switching spin states has been shown previously $[46,47]$ by the theoretical study of the binuclear adducts of cobalt diketonates with di-o-quinone L. In this work, we aimed at enlarging the range of magnetically active compounds and performed the computational modeling of the bimetallic $(\mathrm{Fe}-\mathrm{Fe}$ and $\mathrm{Fe}-\mathrm{Co}$ ) complexes with tetrahydroxyanthracene $\mathrm{L}$ in which tris(2-pyridylmethyl)amine (Tpa) bases $\left(\mathrm{Me}_{n} \mathrm{Tpa}, n=0,2\right)$ played the role of ancillary terminal 
moieties. Hexafluorophosphate anions were chosen because of their wide use for the synthesis of similar saltlike $o$-benzoquinone complexes with tetradentate $\mathrm{N}$-donor ligands. The electronic structures were studied and the geometric, energy, and magnetic characteristics of compounds I-IV $\left(\mathrm{M}=\mathrm{Fe}, \mathrm{Co} ; \mathrm{R}=\mathrm{H}, \mathrm{CH}_{3}\right)$ presented in Scheme 1 were calculated, and the possibility of spin transitions to occur in them was studied. The metalcontaining dicationic moieties of target complexes $\mathbf{I}^{\prime}-\mathbf{I V}$ $\left(\mathrm{M}=\mathrm{Fe}, \mathrm{Co} ; \mathrm{R}=\mathrm{H}, \mathrm{CH}_{3}\right)$ of the general formula $\left[\mathrm{FeM}\left(\mathrm{Me}_{n} \mathrm{Tpa}\right)_{2}(\mathrm{~L})\right]^{2+}(\mathrm{M}=\mathrm{Fe}, \mathrm{Co} ; n=0,2)$ were also considered to reveal the role of the outer-sphere counterions.<smiles>CC12CCC(C)(c3cc(O)c(O)cc31)c1cc(O)c(O)cc12</smiles>

L

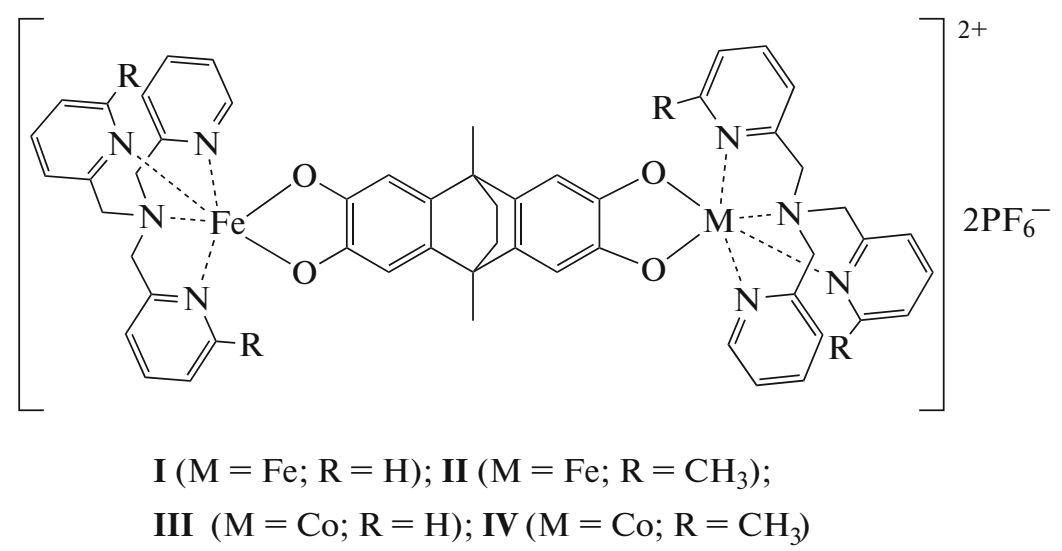

Scheme 1.

\section{CALCULATION PROCEDURE}

The calculations were performed using the Gaussian 16 program [48] by the density functional theory (DFT) method using the UTPSSh functional $[49,50]$ and $6-311++\mathrm{G}(\mathrm{d}, \mathrm{p})$ extended basis set, a combination of which correctly reproduced the energy and magnetic characteristics of the complexes exhibiting the magnetic bistability mechanisms [14, 30, 38, 51-56]. According to the calculation results obtained in this approximation for the experimentally studied cobalt and iron compounds, the spin transitions occur at $\Delta E_{\mathrm{HS}-\mathrm{LS}}<10 \mathrm{kcal} / \mathrm{mol}$. The position and orientation of the hexafluorophosphate counterions in complexes I-IV were taken from the $\mathrm{X}$-ray structure analysis (XSA) data of the structurally similar compounds [14]. The stationary points were localized on the potential energy surface (PES) by the full optimization of the geometry of the molecular structures checking DFT stability of the wave function and calculating the force constants. The exchange interaction parameters $(J$, $\mathrm{cm}^{-1}$ ) were calculated in the framework of the broken symmetry (BS) formalism [57] using the generalized spin projection method proposed by Yamaguchi [58].
The graphical images of the molecular structures were drawn using the ChemCraft program [59].

\section{RESULTS AND DISCUSSION}

According to the calculation results, the ground state of dicationic moiety I' $(\mathrm{M}=\mathrm{Fe}, \mathrm{R}=\mathrm{H})$ corresponds to a minimum on the triplet PES characterized by the localization of the spin density $\left(q_{\mathrm{s}}^{\mathrm{Fe}}, q_{\mathrm{s}}^{\mathrm{M}}=0.45\right)$ on the iron(III) ions (Table 1). The inclusion of the hexafluorophosphate counterions (compound I $(\mathbf{M}=$ $\mathrm{Fe}, \mathrm{R}=\mathrm{H})$ ) in the calculation scheme results in an increase in $q_{\mathrm{s}}^{\mathrm{Fe}}$ and $q_{\mathrm{s}}^{\mathrm{M}}$ to 0.56 indicating that one lone electron is located on each metal center, which allows one to ascribe the electronic structure ${ }_{\mathrm{LS}} \mathrm{Fe}^{\mathrm{III}}-\mathrm{Cat}-$ Cat $-{ }_{\mathrm{LS}} \mathrm{Fe}^{\mathrm{III}}$ to the discussed isomer. It should be mentioned that a significant portion of the spin density is delocalized on the oxygen atoms adjacent to the complexing agent ( 0.14 on each atom), which indicates (along with the determined bond lengths in the $o$-benzoquinone ring (Fig. 1) being intermediate between the distances characteristic of SQ and Cat [60]) the existence of the ${ }_{\mathrm{LS}} \mathrm{Fe}^{\mathrm{II}}-\mathrm{SQ}-\mathrm{SQ}-{ }_{\mathrm{LS}} \mathrm{Fe}^{\mathrm{II}}$ structure with 
Table 1. Spin $(S)$, total energy $(E)$, relative energy $(\Delta E)$, spin-squared operator $\left(S^{2}\right)$, and spin density on the metal centers $\left(q_{\mathrm{s}}^{\mathrm{Fe}}, q_{\mathrm{s}}^{\mathrm{M}}\right)$ in the electromers of complexes I and II and their dicationic moieties I' and II' calculated by the DFT UTPSSh/6-311++G(d,p) method

\begin{tabular}{|c|c|c|c|c|c|c|}
\hline Electromer & $S$ & $E$, a.u. & $\begin{array}{c}\Delta E, \\
\mathrm{kcal} / \mathrm{mol}\end{array}$ & $S^{2}$ & $q_{\mathrm{s}}^{\mathrm{Fe}}$ & $q_{\mathrm{s}}^{\mathrm{M}}$ \\
\hline \multicolumn{7}{|c|}{ Dicationic moiety $\mathbf{I}^{\prime}(\mathrm{M}=\mathrm{Fe}, \mathrm{R}=\mathrm{H})$} \\
\hline${ }_{\mathrm{LS}} \mathrm{Fe}^{\mathrm{III}}-\mathrm{Cat}-\mathrm{Cat}-{ }_{\mathrm{LS}} \mathrm{Fe}^{\mathrm{III}}$ & 1 & -5354.937570 & 0.0 & 2.038 & 0.45 & 0.45 \\
\hline BS & 0 & -5354.938477 & & 0.972 & & \\
\hline${ }_{\mathrm{LS}} \mathrm{Fe}^{\mathrm{III}}-\mathrm{Cat}-\mathrm{Cat}-{ }_{\mathrm{HS}} \mathrm{Fe}^{\mathrm{III}}$ & 3 & -5354.920405 & 10.8 & 12.048 & 0.43 & 4.05 \\
\hline BS & 0 & -5354.921238 & & 6.993 & & \\
\hline${ }_{\mathrm{HS}} \mathrm{Fe}^{\mathrm{III}}-\mathrm{Cat}-\mathrm{Cat}-{ }_{\mathrm{HS}} \mathrm{Fe}^{\mathrm{III}}$ & 5 & -5354.903194 & 21.6 & 30.059 & 4.04 & 4.04 \\
\hline BS & 0 & -5354.903804 & & 5.015 & & \\
\hline \multicolumn{7}{|c|}{$\mathbf{I}(\mathrm{M}=\mathrm{Fe}, \mathrm{R}=\mathrm{H})$} \\
\hline${ }_{\mathrm{LS}} \mathrm{Fe}^{\mathrm{III}}-\mathrm{Cat}-\mathrm{Cat}-{ }_{\mathrm{LS}} \mathrm{Fe}^{\mathrm{III}}$ & 1 & -7236.924456 & 0.0 & 2.052 & 0.56 & 0.56 \\
\hline${ }_{\mathrm{LS}} \mathrm{Fe}^{\mathrm{III}}-\mathrm{Cat}-\mathrm{Cat}-{ }_{\mathrm{HS}} \mathrm{Fe}^{\mathrm{III}}$ & 3 & -7236.906528 & 11.2 & 12.050 & 0.55 & 4.08 \\
\hline${ }_{\mathrm{HS}} \mathrm{Fe}^{\mathrm{III}}-\mathrm{Cat}-\mathrm{Cat}-\mathrm{HS} \mathrm{Fe}^{\mathrm{III}}$ & 5 & -7236.888550 & 22.5 & 30.048 & 4.08 & 4.08 \\
\hline \multicolumn{7}{|c|}{ Dicationic moiety II' $\left(\mathrm{M}=\mathrm{Fe}, \mathrm{R}=\mathrm{CH}_{3}\right)$} \\
\hline${ }_{\mathrm{LS}} \mathrm{Fe}^{\mathrm{III}}-\mathrm{Cat}-\mathrm{Cat}-{ }_{\mathrm{LS}} \mathrm{Fe}^{\mathrm{III}}$ & 1 & -5512.244973 & 0.0 & 2.052 & 0.53 & 0.53 \\
\hline BS & 0 & -5512.245776 & & 0.992 & & \\
\hline${ }_{\mathrm{LS}} \mathrm{Fe}^{\mathrm{III}}-\mathrm{Cat}-\mathrm{Cat}-{ }_{\mathrm{HS}} \mathrm{Fe}^{\mathrm{III}}$ & 3 & -5512.239644 & 3.3 & 12.053 & 0.52 & 4.05 \\
\hline BS & 0 & -5512.240453 & & 6.998 & & \\
\hline${ }_{\mathrm{HS}} \mathrm{Fe}^{\mathrm{III}}-\mathrm{Cat}-\mathrm{Cat}-{ }_{\mathrm{HS}} \mathrm{Fe}^{\mathrm{III}}$ & 5 & -5512.234596 & 6.5 & 30.056 & 4.04 & 4.04 \\
\hline BS & 0 & -5512.235297 & & 5.007 & & \\
\hline \multicolumn{7}{|c|}{$\mathbf{I I}\left(\mathrm{M}=\mathrm{Fe}, \mathrm{R}=\mathrm{CH}_{3}\right)$} \\
\hline${ }_{\mathrm{LS}} \mathrm{Fe}^{\mathrm{III}}-\mathrm{Cat}-\mathrm{Cat}-{ }_{\mathrm{LS}} \mathrm{Fe}^{\mathrm{III}}$ & 1 & -7394.229462 & 0.0 & 2.075 & 0.65 & 0.65 \\
\hline${ }_{\mathrm{LS}} \mathrm{Fe}^{\mathrm{III}}-\mathrm{Cat}-\mathrm{Cat}-{ }_{\mathrm{HS}} \mathrm{Fe}^{\mathrm{III}}$ & 3 & -7394.222740 & 4.2 & 12.064 & 0.66 & 4.08 \\
\hline${ }_{\mathrm{HS}} \mathrm{Fe}^{\mathrm{III}}-\mathrm{Cat}-\mathrm{Cat}-{ }_{\mathrm{HS}} \mathrm{Fe}^{\mathrm{III}}$ & 5 & -7394.217166 & 7.7 & 30.048 & 4.09 & 4.09 \\
\hline
\end{tabular}

a close energy. The data of the experimental studies (XSA, Mössbauer spectroscopy) for the mononuclear iron(III) complexes of similar structure confirm that the electronic configuration ${ }_{\mathrm{LS}} \mathrm{Fe}^{\mathrm{II}}-\mathrm{SQ}$ is admixed to the more preferable state ${ }_{\mathrm{LS}} \mathrm{Fe}^{\mathrm{III}}-\mathrm{Cat}[61,62]$, which is consistent with the obtained calculation results for complex $\mathbf{I}(\mathrm{M}=\mathrm{Fe}, \mathrm{R}=\mathrm{H})$ and its dicationic moiety I'. The study of the exchange interactions in the ${ }_{\mathrm{LS}} \mathrm{Fe}^{\mathrm{III}}-\mathrm{Cat}-\mathrm{Cat}-{ }_{\mathrm{LS}} \mathrm{Fe}^{\mathrm{III}}$ electromer shows a strong antiferromagnetic coupling of lone electron spins $(J=$ $-187 \mathrm{~cm}^{-1}$ ).

The next in energy isomers of complex I $(\mathrm{M}=\mathrm{Fe}$, $\mathrm{R}=\mathrm{H})$ and its dicationic moiety $\mathbf{I}^{\prime}$ are presented by the minima of ${ }_{\mathrm{LS}} \mathrm{Fe}^{\mathrm{III}}-\mathrm{Cat}-\mathrm{Cat}-{ }_{\mathrm{HS}} \mathrm{Fe}^{\mathrm{III}}$ on the septet PES (Table 1, Fig. 1). The absence of spin density on the carbon atoms and an insignificant alternation of the bonds in redox ligand $\mathrm{L}$ indicate its Cat form. The calculated spin density on the metal in the high-spin state is somewhat lower than the value expected for five electrons $\left(q_{\mathrm{s}}^{\mathrm{Fe}}, q_{\mathrm{s}}^{\mathrm{M}} \approx 4\right)$. A similar situation is often observed in the trivalent iron compounds with $o$-benzoquinone ligands [62-65]. A moderate antiferromagnetic exchange $\left(J=-36 \mathrm{~cm}^{-1}\right)$ is expected for the ${ }_{\mathrm{LS}} \mathrm{Fe}^{\mathrm{III}}-\mathrm{Cat}-\mathrm{Cat}-{ }_{\mathrm{HS}} \mathrm{Fe}^{\mathrm{III}}$ isomer. The predicted difference in energies between the ${ }_{\mathrm{LS}} \mathrm{Fe}^{\mathrm{III}}-\mathrm{Cat}-\mathrm{Cat}-$ ${ }_{\mathrm{LS}} \mathrm{Fe}^{\mathrm{III}}$ and ${ }_{\mathrm{LS}} \mathrm{Fe}^{\mathrm{III}}-\mathrm{Cat}-\mathrm{Cat}-{ }_{\mathrm{HS}} \mathrm{Fe}^{\mathrm{III}}$ electromers both ignoring $(10.8 \mathrm{kcal} / \mathrm{mol})$ and taking into account two anions $(11.2 \mathrm{kcal} / \mathrm{mol})$ allows one to expect that the thermally initiated SCO would occur on one of the metal centers.

The HS isomer ${ }_{\mathrm{HS}} \mathrm{Fe}^{\mathrm{III}}-\mathrm{Cat}-\mathrm{Cat}-{ }_{\mathrm{HS}} \mathrm{Fe}^{\mathrm{III}}$ is remote from the ground state ${ }_{\mathrm{LS}} \mathrm{Fe}^{\mathrm{III}}-\mathrm{Cat}-\mathrm{Cat}-$ ${ }_{\mathrm{LS}} \mathrm{Fe}^{\mathrm{III}}$ by more than $20 \mathrm{kcal} / \mathrm{mol}$, indicating a low probability of its population under the thermal conditions. A comparison of the data obtained by the calculation of dicationic moiety I' and electroneutral com- 

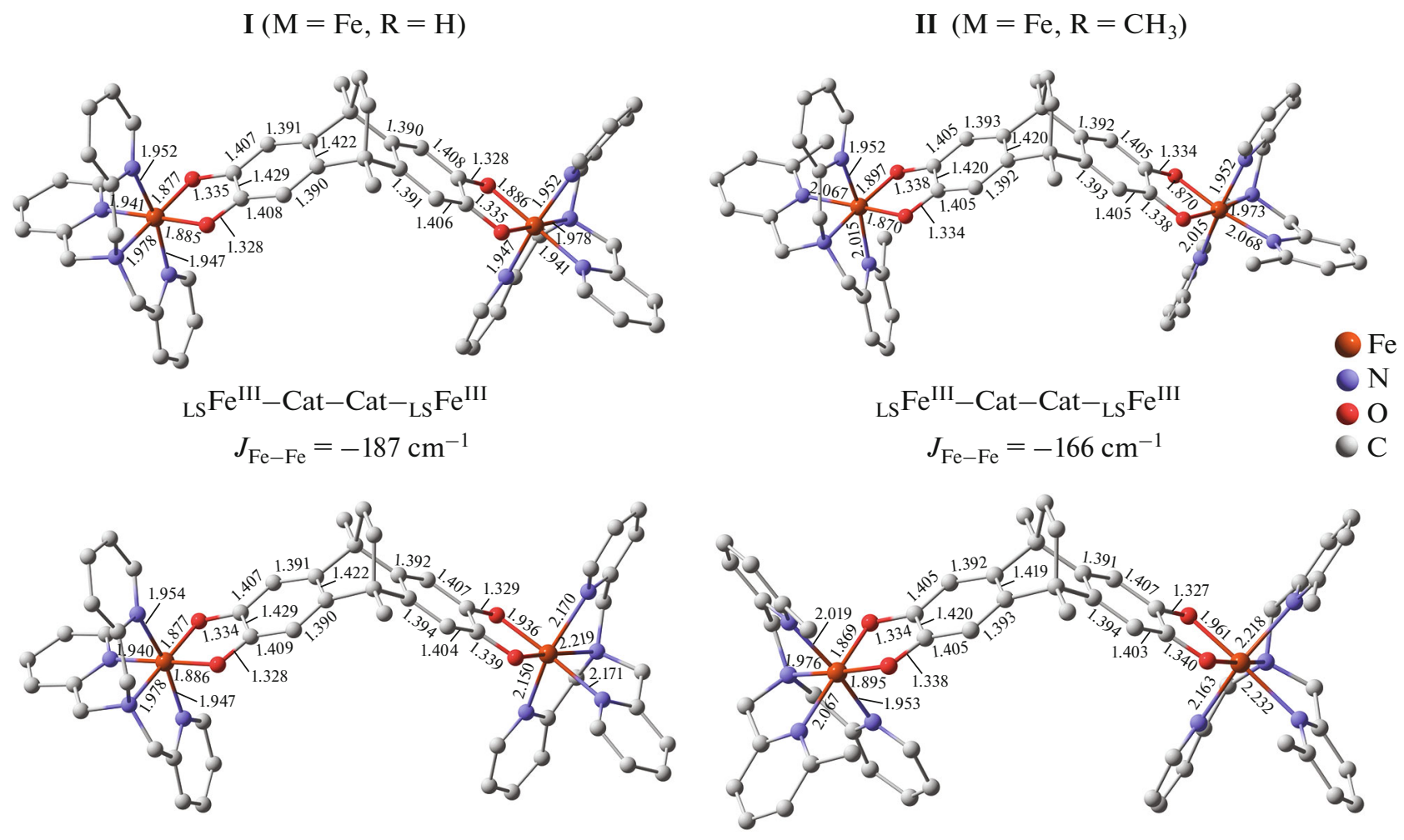

$$
\begin{gathered}
{ }_{\mathrm{LS}} \mathrm{Fe}^{\mathrm{III}}-\mathrm{Cat}-\mathrm{Cat}-{ }_{\mathrm{HS}} \mathrm{Fe}^{\mathrm{III}} \\
J_{\mathrm{Fe}-\mathrm{Fe}}=-36 \mathrm{~cm}^{-1}
\end{gathered}
$$

$$
\begin{gathered}
\mathrm{LS}^{\mathrm{Fe}}{ }^{\mathrm{III}}-\mathrm{Cat}-\mathrm{Cat}-{ }_{\mathrm{HS}} \mathrm{Fe}^{\mathrm{III}} \\
J_{\mathrm{Fe}-\mathrm{Fe}}=-35 \mathrm{~cm}^{-1}
\end{gathered}
$$
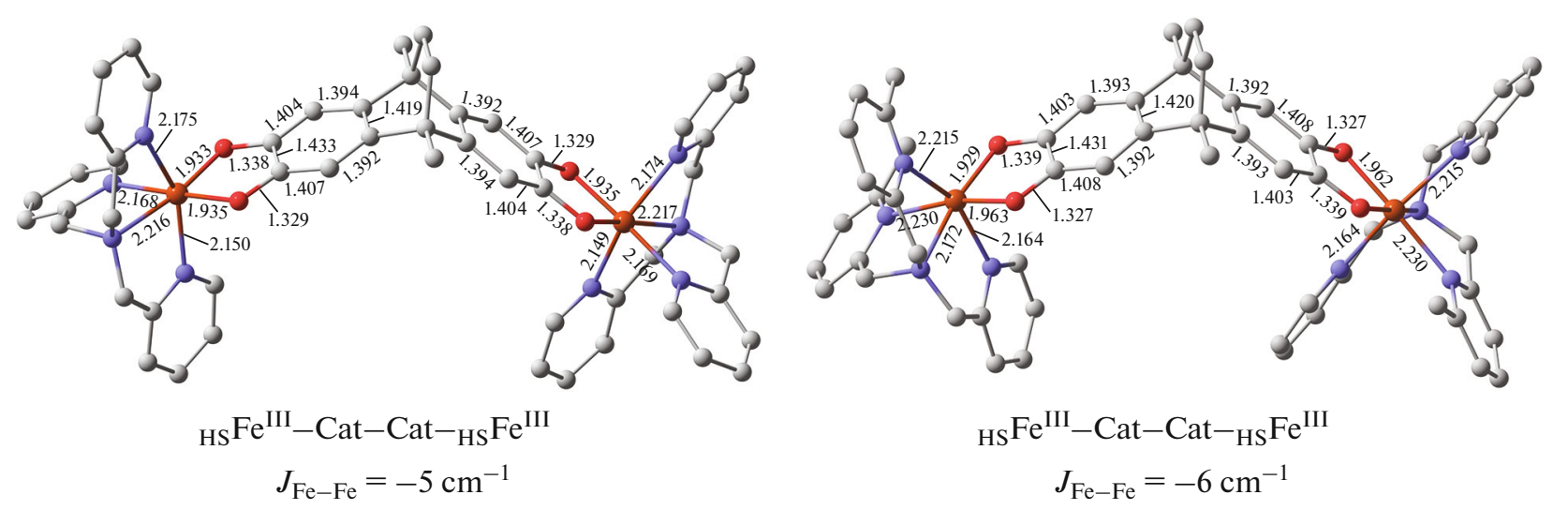

Fig. 1. Calculated data (spatial structures, bond lengths, and exchange parameters) for the electromers of complexes I and II obtained by the DFT UTPSSh/6-311++G(d,p) method. Here and in Fig. 2, the hydrogen atoms and outer-sphere counterions are omitted, and the bond lengths are given in $\AA$.

plex I indicates that the accounting for the counterion exerts no substantial effect on the difference in energies between the electromers involved in the SCO rearrangement $\left({ }_{\mathrm{LS}} \mathrm{Fe}^{+3} \rightleftarrows{ }_{\mathrm{HS}} \mathrm{Fe}^{+3}\right.$ ).

It has previously been shown [14, 29, 34, 38, 42] that the introduction of methyl substituents in the sixth position of the pyridine ring of Tpa creates steric hindrances for the formation of the LS isomer characterized by shorter $\mathrm{M}-\mathrm{N}$ coordination bonds and results in the narrowing of the energy gap between the electromers containing metal ions in different spin states. Electroneutral complexes II $(\mathrm{M}=\mathrm{Fe}, \mathrm{R}=$ $\left.\mathrm{CH}_{3}\right)$ and their dicationic moieties II' $(\mathrm{M}=\mathrm{Fe}, \mathrm{R}=$ $\mathrm{CH}_{3}$ ) in which $\mathrm{Me}_{2}$ Tpa act as ancillary terminal ligands were studied in order to find a compound based on L potentially capable of undergoing two-step SCO rearrangements.

As follows from the obtained calculation results, the functionalization of the tetradentate base does not change the electronic configuration of the determined 
isomers: the values of spin density on the metal centers (Table 1) and calculated bond lengths in the redox moiety (Fig. 1) indicate the trivalent state of iron and catecholate form of ligand $\mathrm{L}$ in all structures. At the same time, the introduction of alkyl groups is expectedly [14, 29, 34, 38, 42] accompanied by a decrease in the stability of the ${ }_{\mathrm{LS}} \mathrm{Fe}^{\mathrm{III}}-\mathrm{Cat}-\mathrm{Cat}-{ }_{\mathrm{LS}} \mathrm{Fe}^{\mathrm{III}}$ and ${ }_{\mathrm{LS}} \mathrm{Fe}^{\mathrm{III}}-\mathrm{Cat}-\mathrm{Cat}-{ }_{\mathrm{HS}} \mathrm{Fe}^{\mathrm{III}}$ electromers containing the LS metal ions. As a consequence, the HS form ${ }_{\mathrm{HS}} \mathrm{Fe}^{\mathrm{III}}-\mathrm{Cat}-\mathrm{Cat}-{ }_{\mathrm{HS}} \mathrm{Fe}^{\mathrm{III}}$ is remote from the ground state ${ }_{\mathrm{LS}} \mathrm{Fe}^{\mathrm{III}}-\mathrm{Cat}-\mathrm{Cat}-{ }_{\mathrm{LS}} \mathrm{Fe}^{\mathrm{III}}$ by less than $8 \mathrm{kcal} / \mathrm{mol}$ (Table 1), which provides the occurrence of the twostep SCO transformation in compound II $(\mathrm{M}=\mathrm{Fe}$, $\mathrm{R}=\mathrm{CH}_{3}$ ).

According to the calculation of the exchange interactions, a strong antiferromagnetic coupling of the metal centers $\left(J=-166 \mathrm{~cm}^{-1}\right)$ that can result in diamagnetism is expected in the $\mathrm{LS}_{\mathrm{LS}} \mathrm{Fe}^{\mathrm{III}}-\mathrm{Cat}-\mathrm{Cat}-$ ${ }_{\mathrm{LS}} \mathrm{Fe}^{\mathrm{III}}$ electromer, the isomer in the intermediate spin state ${ }_{\mathrm{LS}} \mathrm{Fe}^{\mathrm{III}}-\mathrm{Cat}-\mathrm{Cat}-{ }_{\mathrm{HS}} \mathrm{Fe}^{\mathrm{III}}$ exhibits a moderate antiferromagnetic exchange $\left(J=-35 \mathrm{~cm}^{-1}\right)$, and lone electron spins in the HS structure ${ }_{\mathrm{HS}} \mathrm{Fe}^{\mathrm{III}}-\mathrm{Cat}-\mathrm{Cat}-$ ${ }_{\mathrm{HS}} \mathrm{Fe}^{\mathrm{III}}$ do not almost interact $\left(J=-6 \mathrm{~cm}^{-1}\right)$. Thus, the total spin of the system $(S)$ would change from $S=0$ to $S=5$ during the predicted spin transitions in complex II $\left(\mathrm{M}=\mathrm{Fe}, \mathrm{R}=\mathrm{CH}_{3}\right)$, which allows one to consider this compound as a basis for molecular switches.

The quantum chemical study of heterometallic compounds III and IV and their dicationic moieties III' and IV' shows that the LS $(S=1 / 2)$ electromers contain the dicatecholate form of $\mathrm{L}$ and three-charged metal ions (Table 2), and the single electron in the ${ }_{\mathrm{LS}} \mathrm{Fe}^{\mathrm{III}}-\mathrm{Cat}-\mathrm{Cat}-{ }_{\mathrm{LS}} \mathrm{Co}^{\mathrm{III}}$ isomers is concentrated on the iron center $\left(q_{\mathrm{s}}^{\mathrm{Fe}} \approx 0.5\right)$ when a significant portion of the spin density is delocalized over the adjacent donor atoms. Two types of structures were found on the sextet PES: the ${ }_{\mathrm{LS}} \mathrm{Fe}^{\mathrm{III}}-\mathrm{Cat}-\mathrm{SQ}-{ }_{\mathrm{HS}} \mathrm{Co}^{\mathrm{II}}$ isomer containing three paramagnetic centers ${ }_{\mathrm{LS}} \mathrm{Fe}^{\mathrm{III}}, \mathrm{SQ}$, ${ }_{\mathrm{HS}} \mathrm{Co}^{\mathrm{II}}$ ) and the ${ }_{\mathrm{HS}} \mathrm{Fe}^{\mathrm{III}}-\mathrm{Cat}-\mathrm{Cat}-{ }_{\mathrm{LS}} \mathrm{Co}^{\mathrm{III}}$ electromer in which five lone electrons are localized on the iron(III) ion in the HS state. The structure with the highest spin $(S=9 / 2)$ is presented by the electronic configuration ${ }_{\mathrm{HS}} \mathrm{Fe}^{\mathrm{III}}-\mathrm{Cat}-\mathrm{SQ}-{ }_{\mathrm{HS}} \mathrm{Co}^{\mathrm{II}}$.

The calculated difference in energies between the most stable isomers of complex III and its dicationic moiety III' does not exceed $10 \mathrm{kcal} / \mathrm{mol}$ and allows one to expect the VT rearrangement in the cobalt moiety of the molecule: ${ }_{\mathrm{LS}} \mathrm{Fe}^{\mathrm{III}}-\mathrm{Cat}-\mathrm{Cat}-{ }_{\mathrm{LS}} \mathrm{Co}^{\mathrm{III}} \rightleftarrows$ ${ }_{\mathrm{LS}} \mathrm{Fe}^{\mathrm{III}}-\mathrm{Cat}-\mathrm{SQ}-{ }_{\mathrm{HS}} \mathrm{Co}^{\mathrm{II}}$ (Fig. 2). The discussed values of $\Delta E$ ignoring $(5.3 \mathrm{kcal} / \mathrm{mol})$ and taking into account the hexafluorophosphate anions $(9.9 \mathrm{kcal} / \mathrm{mol})$ differ nearly by a factor of 2 , which is consistent with the earlier revealed [29, 30, 42, 54] overestimation of the stabilization energy of the HS electromers by the DFT study of the cationic cobalt complexes with the redox ligands and confirms the importance of inclusion of the outer-sphere counterions in the calculation scheme. This fact is caused, most probably, by the charge redistribution in the redox moiety during the VT transformation $\mathrm{Co}^{+3}-$ $\mathrm{Cat}^{2-} \rightleftarrows \mathrm{Co}^{+2}-\mathrm{SQ}^{--}$, which is reflected as different strengths of the Coulomb interactions of the valence tautomers with the outer-sphere counterion. A comparison of the calculated energy characteristics of compound IV and its structural moiety IV' (Table 2) is more clear: in the case of dicationic system IV', the ${ }_{\mathrm{LS}} \mathrm{Fe}^{\mathrm{III}}-\mathrm{Cat}-\mathrm{SQ}-{ }_{\mathrm{HS}} \mathrm{Co}^{\mathrm{II}}$ isomer turns out to be the most stable, whereas the accounting for $\mathrm{PF}_{6}^{-}$(complex IV) results in the inversion of the relative energies and stabilization of the ${ }_{\mathrm{LS}} \mathrm{Fe}^{\mathrm{III}}-\mathrm{Cat}-\mathrm{Cat}-{ }_{\mathrm{LS}} \mathrm{Co}^{\mathrm{III}}$ electromer.

The predicted difference in energies between the isomers of complex III $(\mathrm{M}=\mathrm{Co}, \mathrm{R}=\mathrm{H})$ differed in the spin state of the iron(III) ion (Table 2, Fig. 2) indicates the possibility of the SCO process ${ }_{\mathrm{LS}} \mathrm{Fe}^{\mathrm{III}}-\mathrm{Cat}-$ Cat $-{ }_{\mathrm{LS}} \mathrm{Co}^{\mathrm{III}} \rightleftarrows{ }_{\mathrm{HS}} \mathrm{Fe}^{\mathrm{III}}-\mathrm{Cat}-\mathrm{Cat}-{ }_{\mathrm{LS}} \mathrm{Co}^{\mathrm{III}}$, which was not completed under the thermal conditions. A significant destabilization of the $\mathrm{HS}$ form ${ }_{\mathrm{HS}} \mathrm{Fe}^{\mathrm{III}}-\mathrm{Cat}-$ $\mathrm{SQ}-{ }_{\mathrm{HS}} \mathrm{Co}^{\mathrm{II}}$ does not allow one to expect its participation in spin transitions. Thus, heterometallic complex III can demonstrate two transformations leading to switching the magnetic properties: VT on the cobalt center and SCO on the iron(III) ion. Since the antiferromagnetic exchange interactions between ${ }_{\mathrm{LS}} \mathrm{Fe}^{\mathrm{III}}$ and SQ $\left(J=-265 \mathrm{~cm}^{-1}\right)$ in the ${ }_{\mathrm{LS}} \mathrm{Fe}^{\mathrm{III}}-\mathrm{Cat}-\mathrm{SQ}-{ }_{\mathrm{HS}} \mathrm{Co}^{\mathrm{II}}$ isomer are expected to be strong, the first rearrangement would be accompanied by a change in the spin from $1 / 2$ to $3 / 2$ and the SCO would induce transitions between the doublet $(S=1 / 2)$ and sextet $(S=5 / 2)$ states.

The closeness of the total energies of four electromers of complex IV $\left(\mathrm{M}=\mathrm{Co}, \mathrm{R}=\mathrm{CH}_{3}\right)$ assumes the possibility of each of them (Table 2, Fig. 2) to be involved in spin transitions. The transformation of the LS form into the HS form can proceed via three equally probable mechanisms: (1) the process ${ }_{\mathrm{LS}} \mathrm{Fe}^{\mathrm{III}}-$ Cat-Cat- ${ }_{\mathrm{LS}} \mathrm{Co}^{\mathrm{III}} \rightleftarrows{ }_{\mathrm{LS}} \mathrm{Fe}^{\mathrm{III}}-\mathrm{Cat}-\mathrm{SQ}-{ }_{\mathrm{HS}} \mathrm{Co}^{\mathrm{II}}$ caused by the electron transfer between the redox ligand and cobalt(II) ion followed by the SCO rearrangement on the $\mathrm{Fe}(\mathrm{III})$ center ${ }_{\mathrm{LS}} \mathrm{Fe}^{\mathrm{III}}-\mathrm{Cat}-\mathrm{SQ}-{ }_{\mathrm{HS}} \mathrm{Co}^{\mathrm{II}} \rightleftarrows$ ${ }_{\mathrm{HS}} \mathrm{Fe}^{\mathrm{III}}-\mathrm{Cat}-\mathrm{SQ}-{ }_{\mathrm{HS}} \mathrm{Co}^{\mathrm{II}}$, (2) sequential phenomena of $\mathrm{SCO}\left({ }_{\mathrm{LS}} \mathrm{Fe}^{\mathrm{III}}-\mathrm{Cat}-\mathrm{Cat}-{ }_{\mathrm{LS}} \mathrm{Co}^{\mathrm{III}} \rightleftarrows{ }_{\mathrm{HS}} \mathrm{Fe}^{\mathrm{III}}-\mathrm{Cat}-\right.$ $\mathrm{Cat}-{ }_{\mathrm{LS}} \mathrm{Co}{ }^{\mathrm{III}}$ ) and $\mathrm{VT}\left({ }_{\mathrm{HS}} \mathrm{Fe}^{\mathrm{III}}-\mathrm{Cat}-\mathrm{Cat}-{ }_{\mathrm{LS}} \mathrm{Co}^{\mathrm{III}} \rightleftarrows\right.$ ${ }_{\mathrm{HS}} \mathrm{Fe}^{\mathrm{III}}-\mathrm{Cat}-\mathrm{SQ}-{ }_{\mathrm{HS}} \mathrm{Co}^{\mathrm{II}}$ ), and (3) synchronized mechanisms of magnetic bistability $\mathrm{SCO}+\mathrm{VT}$ ( $\mathrm{LS} \mathrm{Fe}^{\mathrm{III}}-\mathrm{Cat}-\mathrm{Cat}-{ }_{\mathrm{LS}} \mathrm{Co}^{\mathrm{III}} \rightleftarrows \mathrm{HS}^{\mathrm{II}} \mathrm{Fe}^{\mathrm{III}}-\mathrm{Cat}-\mathrm{SQ}-$ $\left.{ }_{\mathrm{HS}} \mathrm{Co}^{\mathrm{II}}\right)$. In the ${ }_{\mathrm{LS}} \mathrm{Fe}^{\mathrm{III}}-\mathrm{Cat}-\mathrm{SQ}-{ }_{\mathrm{HS}} \mathrm{Co}^{\mathrm{II}}$ and ${ }_{\mathrm{HS}} \mathrm{Fe}^{\mathrm{III}}-$ Cat-SQ- ${ }_{\mathrm{HS}} \mathrm{Co}^{\mathrm{II}}$ isomers, two metal centers do not nearly interact $\left(J<3 \mathrm{~cm}^{-1}\right)$ and the HS cobalt(II) ion 
Table 2. Spin $(S)$, total energy $(E)$, relative energy $(\Delta E)$, spin-squared operator $\left(S^{2}\right)$, and spin density on the metal centers $\left(q_{\mathrm{s}}^{\mathrm{Fe}}, q_{\mathrm{s}}^{\mathrm{M}}\right)$ in the electromers of complexes III and IV and their dicationic moieties III' and IV' calculated by the DFT UTPSSh $/ 6-311++G(\mathrm{~d}, \mathrm{p})$ method

\begin{tabular}{|c|c|c|c|c|c|c|}
\hline Electromer & $S$ & $E$, a.u. & $\begin{array}{c}\Delta E, \\
\mathrm{kcal} / \mathrm{mol}\end{array}$ & $S^{2}$ & $q_{\mathrm{s}}^{\mathrm{Fe}}$ & $q_{\mathrm{s}}^{\mathrm{M}}$ \\
\hline \multicolumn{7}{|c|}{ Dicationic moiety III' $(\mathrm{M}=\mathrm{Co}, \mathrm{R}=\mathrm{H})$} \\
\hline${ }_{\mathrm{LS}} \mathrm{Fe}^{\mathrm{III}}-\mathrm{Cat}-\mathrm{Cat}-{ }_{\mathrm{LS}} \mathrm{Co}^{\mathrm{III}}$ & $1 / 2$ & -5473.971117 & 0.0 & 0.765 & 0.37 & 0.00 \\
\hline${ }_{\mathrm{LS}} \mathrm{Fe}^{\mathrm{III}}-\mathrm{Cat}-\mathrm{SQ}-{ }_{\mathrm{HS}} \mathrm{Co}^{\mathrm{II}}$ & $5 / 2$ & -5473.962600 & 5.3 & 8.785 & 0.48 & 2.80 \\
\hline$\beta \alpha \alpha^{*}$ & $3 / 2$ & -5473.963854 & & 4.702 & & \\
\hline$\alpha \beta \alpha$ & $3 / 2$ & -5473.961945 & & 4.667 & & \\
\hline$\alpha \alpha \beta$ & $1 / 2$ & -5473.960567 & & 2.761 & & \\
\hline${ }_{\mathrm{HS}} \mathrm{Fe}^{\mathrm{III}}-\mathrm{Cat}-\mathrm{Cat}-{ }_{\mathrm{LS}} \mathrm{Co}^{\mathrm{III}}$ & $5 / 2$ & -5473.953431 & 11.1 & 8.785 & 4.02 & 0.00 \\
\hline $\mathrm{HS} \mathrm{Fe}^{\mathrm{III}}-\mathrm{Cat}-\mathrm{SQ}-{ }_{\mathrm{HS}} \mathrm{Co}^{\mathrm{II}}$ & $9 / 2$ & -5473.945618 & 16.0 & 24.792 & 4.06 & 2.80 \\
\hline$\beta \alpha \alpha$ & $1 / 2$ & -5473.946583 & & 4.701 & & \\
\hline$\alpha \beta \alpha$ & $7 / 2$ & -5473.944834 & & 16.693 & & \\
\hline$\alpha \alpha \beta$ & $3 / 2$ & -5473.943411 & & 6.766 & & \\
\hline \multicolumn{7}{|c|}{ III $(\mathrm{M}=\mathrm{Co}, \mathrm{R}=\mathrm{H})$} \\
\hline${ }_{\mathrm{LS}} \mathrm{Fe}^{\mathrm{III}}-\mathrm{Cat}-\mathrm{Cat}-{ }_{\mathrm{LS}} \mathrm{Co}^{\mathrm{III}}$ & $1 / 2$ & -7355.961933 & 0.0 & 0.772 & 0.49 & 0.00 \\
\hline${ }_{\mathrm{LS}} \mathrm{Fe}^{\mathrm{III}}-\mathrm{Cat}-\mathrm{SQ}-{ }_{\mathrm{HS}} \mathrm{Co}^{\mathrm{II}}$ & $5 / 2$ & -7355.946107 & 9.9 & 8.794 & 0.60 & 2.82 \\
\hline${ }_{\mathrm{HS}} \mathrm{Fe}^{\mathrm{III}}-\mathrm{Cat}-\mathrm{Cat}-{ }_{\mathrm{LS}} \mathrm{Co}^{\mathrm{III}}$ & $5 / 2$ & -7355.943379 & 11.6 & 8.780 & 4.07 & 0.00 \\
\hline${ }_{\mathrm{HS}} \mathrm{Fe}^{\mathrm{III}}-\mathrm{Cat}-\mathrm{SQ}-{ }_{\mathrm{HS}} \mathrm{Co}^{\mathrm{II}}$ & $9 / 2$ & -7355.928050 & 21.3 & 24.788 & 4.10 & 2.81 \\
\hline \multicolumn{7}{|c|}{ Dicationic moiety IV' $\left(\mathrm{M}=\mathrm{Co}, \mathrm{R}=\mathrm{CH}_{3}\right)$} \\
\hline${ }_{\mathrm{LS}} \mathrm{Fe}^{\mathrm{III}}-\mathrm{Cat}-\mathrm{Cat}-{ }_{\mathrm{LS}} \mathrm{Co}^{\mathrm{III}}$ & $1 / 2$ & -5631.275676 & 0.0 & 0.770 & 0.46 & 0.00 \\
\hline${ }_{\mathrm{LS}} \mathrm{Fe}^{\mathrm{III}}-\mathrm{Cat}-\mathrm{SQ}-{ }_{\mathrm{HS}} \mathrm{Co}^{\mathrm{II}}$ & $5 / 2$ & -5631.279327 & -2.3 & 8.792 & 0.58 & 2.81 \\
\hline$\beta \alpha \alpha$ & $3 / 2$ & -5631.280491 & & 4.714 & & \\
\hline$\alpha \beta \alpha$ & $3 / 2$ & -5631.278009 & & 4.695 & & \\
\hline$\alpha \alpha \beta$ & $1 / 2$ & -5631.276798 & & 2.786 & & \\
\hline${ }_{\mathrm{HS}} \mathrm{Fe}^{\mathrm{III}}-\mathrm{Cat}-\mathrm{Cat}-{ }_{\mathrm{LS}} \mathrm{Co}^{\mathrm{III}}$ & $5 / 2$ & -5631.270361 & 3.3 & 8.781 & 4.03 & 0.00 \\
\hline${ }_{\mathrm{HS}} \mathrm{Fe}^{\mathrm{III}}-\mathrm{Cat}-\mathrm{SQ}-{ }_{\mathrm{HS}} \mathrm{Co}^{\mathrm{II}}$ & $9 / 2$ & -5631.274188 & 0.9 & 24.790 & 4.06 & 2.81 \\
\hline$\beta \alpha \alpha$ & $1 / 2$ & -5631.275290 & & 4.720 & & \\
\hline$\alpha \beta \alpha$ & $7 / 2$ & -5631.272824 & & 16.702 & & \\
\hline$\alpha \alpha \beta$ & $3 / 2$ & -5631.271634 & & 6.785 & & \\
\hline \multicolumn{7}{|c|}{$\mathbf{I V}\left(\mathrm{M}=\mathrm{Co}, \mathrm{R}=\mathrm{CH}_{3}\right)$} \\
\hline${ }_{\mathrm{LS}} \mathrm{Fe}^{\mathrm{III}}-\mathrm{Cat}-\mathrm{Cat}-{ }_{\mathrm{LS}} \mathrm{Co}^{\mathrm{III}}$ & $1 / 2$ & -7513.263112 & 0.0 & 0.779 & 0.59 & 0.00 \\
\hline${ }_{\mathrm{LS}} \mathrm{Fe}^{\mathrm{III}}-\mathrm{Cat}-\mathrm{SQ}-{ }_{\mathrm{HS}} \mathrm{Co}^{\mathrm{II}}$ & $5 / 2$ & -7513.260727 & 1.5 & 8.806 & 0.61 & 2.81 \\
\hline${ }_{\mathrm{HS}} \mathrm{Fe}^{\mathrm{III}}-\mathrm{Cat}-\mathrm{Cat}-{ }_{\mathrm{LS}} \mathrm{Co}^{\mathrm{III}}$ & $5 / 2$ & -7513.258541 & 2.9 & 8.777 & 4.06 & 0.00 \\
\hline${ }_{\mathrm{HS}} \mathrm{Fe}^{\mathrm{III}}-\mathrm{Cat}-\mathrm{SQ}-{ }_{\mathrm{HS}} \mathrm{Co}^{\mathrm{II}}$ & $9 / 2$ & -7513.255784 & 4.6 & 24.787 & 4.10 & 2.82 \\
\hline
\end{tabular}

* $\alpha$ corresponds to the up orientation of spins, and $\beta$ corresponds to the down orientation: $1, \mathrm{Fe}^{\mathrm{III}} ; 2, \mathrm{SQ}$; and $3, \mathrm{Co}^{\mathrm{II}}$.

is ferromagnetically coupled with the semiquinone radical anion $\left(J=183 \mathrm{~cm}^{-1}\right)$, which is consistent with the earlier performed theoretical and experimental studies of the cobalt(II) $o$-benzosemiquinone complexes with the Tpa derivatives [14, 29, 34, 38, 42], whereas the exchange between the Fe(III) center and $\mathrm{SQ}$ is antiferromagnetic. Moderate interactions in the pair of ${ }_{\mathrm{HS}} \mathrm{Fe}^{\mathrm{III}}$ and SQ $\left(J=-50 \mathrm{~cm}^{-1}\right)$ would not affect the total spin $(S=9 / 2)$ of the ${ }_{\mathrm{HS}} \mathrm{Fe}^{\mathrm{III}}-\mathrm{Cat}-\mathrm{SQ}-$ ${ }_{\mathrm{HS}} \mathrm{Co}^{\mathrm{II}}$ structure, but the strong antiferromagnetic 

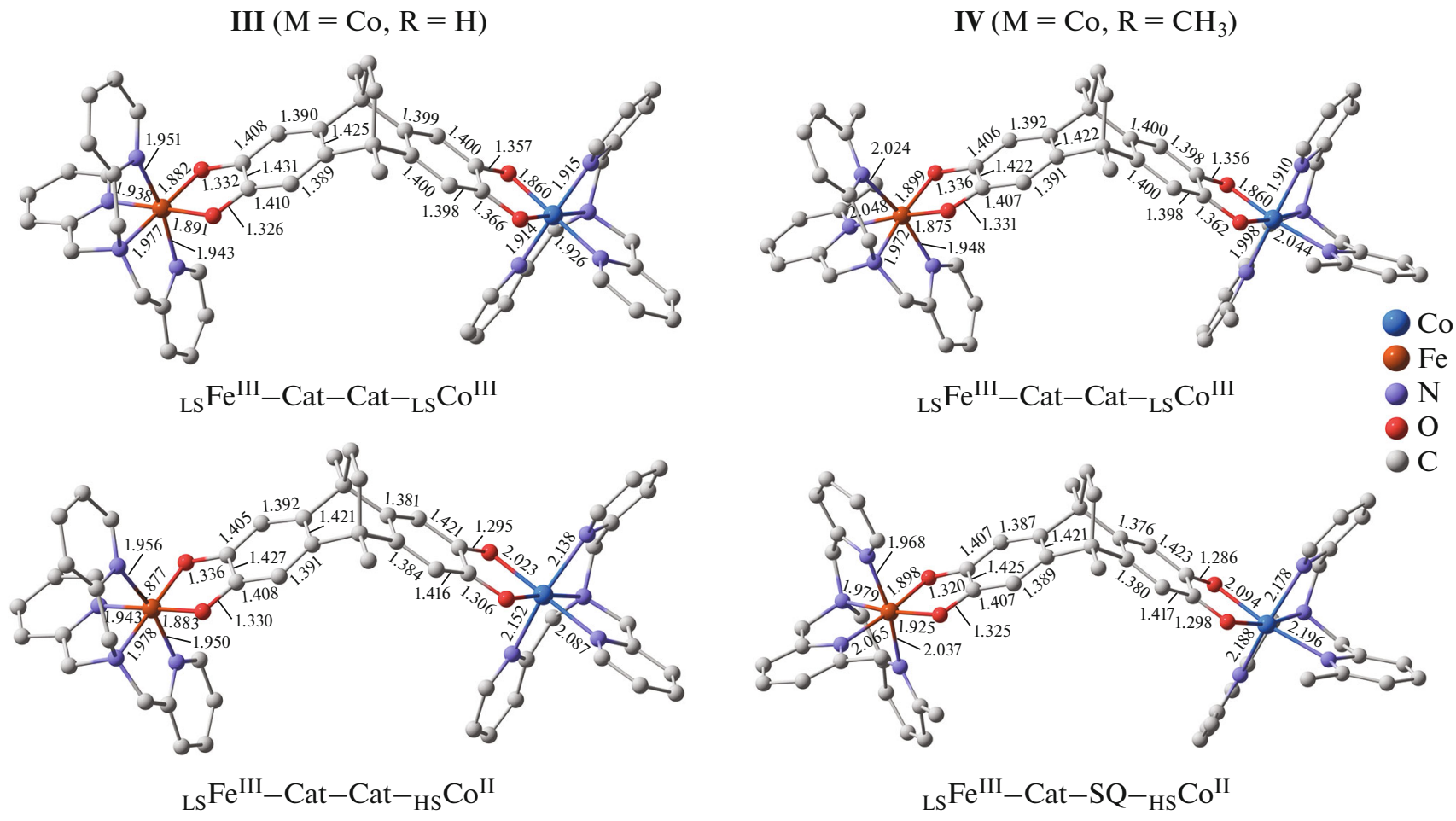

${ }_{\mathrm{LS}} \mathrm{Fe}^{\mathrm{III}}-\mathrm{Cat}-\mathrm{Cat}-{ }_{\mathrm{HS}} \mathrm{Co}^{\mathrm{II}}$

$J_{\mathrm{Fe}-\mathrm{SQ}}=-240 \mathrm{~cm}^{-1} \quad J_{\mathrm{SQ}-\mathrm{Co}}=183 \mathrm{~cm}^{-1} \quad J_{\mathrm{Fe}-\mathrm{Co}}=2 \mathrm{~cm}^{-1}$
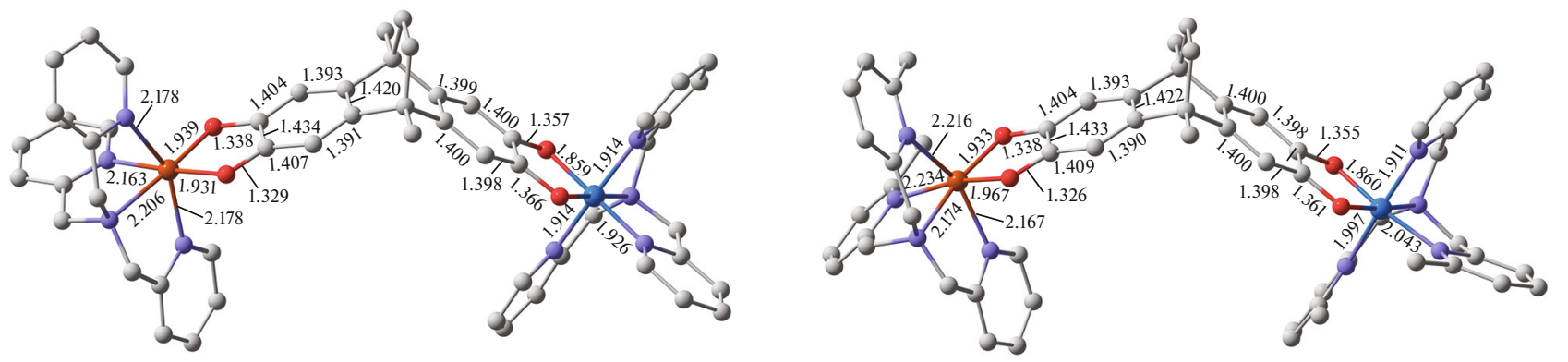

$$
{ }_{\mathrm{HS}} \mathrm{Fe}^{\mathrm{III}}-\mathrm{Cat}-\mathrm{Cat}-{ }_{\mathrm{LS}} \mathrm{Co}{ }^{\mathrm{III}}
$$

$$
{ }_{\mathrm{HS}} \mathrm{Fe}^{\mathrm{III}}-\mathrm{Cat}-\mathrm{Cat}-{ }_{\mathrm{LS}} \mathrm{Co}^{\mathrm{III}}
$$

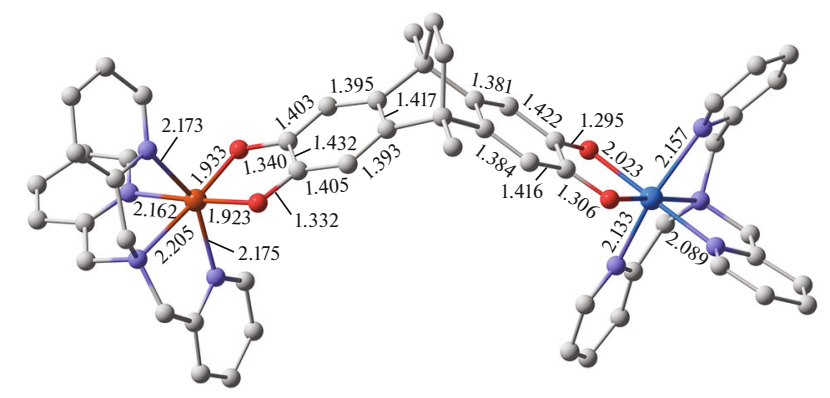

$$
{ }_{\mathrm{HS}} \mathrm{Fe}^{\mathrm{III}}-\mathrm{Cat}-\mathrm{SQ}-{ }_{\mathrm{HS}} \mathrm{Co}^{\mathrm{II}}
$$

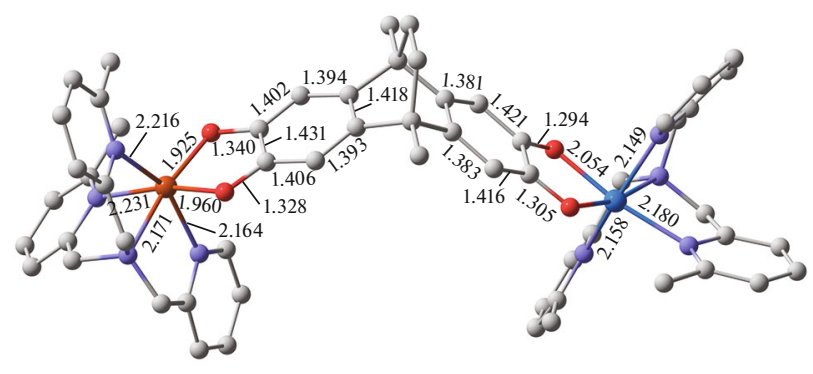

$$
{ }_{\mathrm{HS}} \mathrm{Fe}^{\mathrm{III}}-\mathrm{Cat}-\mathrm{SQ}-{ }_{\mathrm{HS}} \mathrm{Co}^{\mathrm{II}}
$$

$J_{\mathrm{Fe}-\mathrm{SQ}}=-52 \mathrm{~cm}^{-1} \quad J_{\mathrm{SQ}-\mathrm{Co}}=144 \mathrm{~cm}^{-1} \quad J_{\mathrm{Fe}-\mathrm{Co}}=3 \mathrm{~cm}^{-1}$

$J_{\mathrm{Fe}-\mathrm{SQ}}=-50 \mathrm{~cm}^{-1} \quad J_{\mathrm{SQ}-\mathrm{Co}}=183 \mathrm{~cm}^{-1} \quad J_{\mathrm{Fe}-\mathrm{Co}}=1 \mathrm{~cm}^{-1}$

Fig. 2. Calculated data (spatial structures, bond lengths, and exchange parameters) for the electromers of complexes III and IV obtained by the DFT UTPSSh/6-311++G(d,p) method. 
coupling between ${ }_{\mathrm{LS}} \mathrm{Fe}^{\mathrm{III}}$ and SQ $\left(J=-240 \mathrm{~cm}^{-1}\right)$ can result in the stabilization of the ${ }_{\mathrm{LS}} \mathrm{Fe}^{\mathrm{III}}-\mathrm{Cat}-\mathrm{SQ}-$ ${ }_{\mathrm{HS}} \mathrm{Co}^{\mathrm{II}}$ electromer in the state $S=3 / 2$. Therefore, the expected mutual transformations of the isomers of coordination compound IV $\left(\mathrm{M}=\mathrm{Co}, \mathrm{R}=\mathrm{CH}_{3}\right)$ characterized by different values of $S$ (Table 2, Fig. 2) would be accompanied by switching of the magnetic properties in a wide range, which makes the considered heterometallic mixed-ligand complex to become a promising candidate for the design of molecular switches and spin qubits (quantum bits).

Thus, the magnetically active bimetallic coordination compounds in which 9,10-dimethyl-9,10-ethano9,10-dihydro-2,3,6,7-tetrahydroxyanthracene acted as the bridging ligand were modeled and studied by quantum chemical calculations. The complexes that can manifest one- and two-step spin transitions and synchronized SCO and VT mechanisms were theoretically designed by the building up of the coordination sphere of the metals ( $\mathrm{Fe}, \mathrm{Co}$ ) by tris(2-pyridylmethyl)amine bases. The variation of the structural parameters in the ancillary $\mathrm{N}$-donor ligands was found to exert no effect on the character and strength of exchange interactions between the paramagnetic centers but allowed one to control the relative energies of the electromers. The study of the heterospin complexes containing the cobalt ions prone to the participation in the intramolecular electron transfer with the redox ligand ascertained the importance of including the outer-sphere counterions in the calculation scheme. The compounds discussed in this article are promising building blocks for the production of magnetic materials and, hence, are being presently synthesized.

\section{FUNDING}

This work was supported by the Russian Science Foundation, project no. 20-73-00052.

\section{CONFLICT OF INTEREST}

The authors declare that they have no conflicts of interest.

\section{OPEN ACCESS}

This article is licensed under a Creative Commons Attribution 4.0 International License, which permits use, sharing, adaptation, distribution and reproduction in any medium or format, as long as you give appropriate credit to the original author(s) and the source, provide a link to the Creative Commons licence, and indicate if changes were made. The images or other third party material in this article are included in the article's Creative Commons licence, unless indicated otherwise in a credit line to the material. If material is not included in the article's Creative Commons licence and your intended use is not permitted by statutory regulation or exceeds the permitted use, you will need to obtain permission directly from the copyright holder. To view a copy of this licence, visit ttp://creativecommons.org/licenses/by/4.0/.

\section{REFERENCES}

1. Poddel'sky, A.I., Cherkasov, V.K., and Abakumov, G.A., Coord. Chem. Rev., 2009, vol. 253, nos. 3-4, p. 291.

2. Witt, A., Heinemann, F.W., Sproules, S., and Khusniyarov, M.M., Chem.-Eur. J., 2014, vol. 20, no. 35, p. 11149.

3. Sato, O., Nature Chem., 2016, vol. 8, no. 7, p. 644.

4. Calzolari, A., Chen, Y., Lewis, G.F., et al., J. Phys. Chem. B, 2012, vol. 116, no. 43, p. 13141.

5. Sato, O., Tao, J., and Zhang, Y.-Z., Angew. Chem., Int. Ed., 2007, vol. 46, no. 13, p. 2152.

6. Ershova, I.V., Piskunov, A.V., and Cherkasov, V.K., Russ. Chem. Rev., 2020, vol. 89, no. 11, p. 1157.

7. Bubnov, M.P., Piskunov, A.V., Zolotukhin, A.A., et al., Russ. J. Coord. Chem., 2020, vol. 46, no. 4, p. 224. https://doi.org/10.1134/S107032842003001X

8. Zolotukhin, A.A., Bubnov, M.P., Cherkasov, V.K., and Abakumov, G.A., Russ. J. Coord. Chem., 2018, vol. 44, no. 4, p. 272. https://doi.org/10.1134/S1070328418040085

9. Chegerev, M.G. and Piskunov, A.V., Russ. J. Coord. Chem., 2018, vol. 44, no. 4, p. 258. https://doi.org/10.1134/S1070328418040036

10. Demir, S., Jeon, I.-R., Long, J.R., and Harris, T.D., Coord. Chem. Rev., 2015, vol. 289-290, p. 149.

11. Bally, T., Nature Chem., 2010, vol. 2, no. 3, p. 165.

12. Teki, Y., Shirokoshi, M., Kanegawa, S., and Sato, O., Eur. J. Inorg. Chem., 2011, no. 25, p. 3761.

13. Madadi, A., Itazaki, M., Gable, R.W., et al., Eur. J. Inorg. Chem., 2015, no. 30, p. 4991.

14. Gransbury, G.K., Livesay, B.N., Janetzki, J.T., et al., J. Am. Chem. Soc., 2020, vol. 142, no. 24, p. 10692.

15. Alley, K.G., Poneti, G., Aitken, J.B., et al., Inorg. Chem., 2012, vol. 51, no. 7, p. 3944.

16. Alley, K.G., Poneti, G., Robinson, P.S.D., et al., J. Am. Chem. Soc., 2013, vol. 135, no. 22, p. 8304.

17. Miller, J.S. and Min, K.S., Angew. Chem., Int. Ed. Engl., 2009, vol. 48, no. 2, p. 262.

18. Coronado, E., Nat. Rev. Mater., 2020, vol. 5, p. 87.

19. Minkin, V.I., Starikova, A.A., and Starikov, A.G., Dalton Trans., 2016, vol. 45, no. 30, p. 12103.

20. Spin-Crossover Materials: Properties and Applications, Halcrow, M.A., Ed. Chichester: Wiley, 2013.

21. Spin Crossover in Transition Metal Compounds. Topics in Curr. Chem., Gütlich, P. and Goodwin, H.A., Eds. Berlin: Springer, 2004, vols. 233-235.

22. Tezgerevska, T., Alley, K.G., and Boskovic, C., Coord. Chem. Rev., 2014, vol. 268, p. 23.

23. Evangelio, E. and Ruiz-Molina, D., Eur. J. Inorg. Chem., 2005, no. 15, p. 2957.

24. Buchanan, R.M. and Pierpont, C.G., J. Am. Chem. Soc., 1980, vol. 102, no. 15, p. 4951. 
25. Halcrow, M.A., Polyhedron, 2007, vol. 26, no. 14, p. 3523.

26. Harding, D.J., Harding, P., and Phonsri, W., Coord. Chem. Rev., 2016, vol. 313, p. 38.

27. Shultz, D.A., Magnetism: Molecules to Materials II, Miller J.S. and Drillon, M., Eds., New York: Wiley, 2001, pp. 281-306.

28. Mortel, M., Seller, M., Heinemann, F.W., and Khusniyarov, M.M., Dalton Trans., 2020, vol. 49, no. 48, p. 17532.

29. Starikova, A.A., Chegerev, M.G., and Starikov, A.G., Russ. J. Coord. Chem., 2020, vol. 46, no. 3, p. 193. https://doi.org/10.1134/S1070328420030070

30. Tezgerevska, T., Rousset, E., Gable, R.W., et al., Dalton Trans., 2019, vol. 48, no. 31, p. 11674.

31. Graf, M., Wolmershauser, G., Kelm, H., et al., Angew. Chem., Int. Ed. Engl., 2010, vol. 49, no. 5, p. 950.

32. Gransbury, G.K., Boulon, M.-E., Petrie, S., et al., Inorg. Chem., 2019, vol. 58, no. 7, p. 4230.

33. Dei, A. and Sorace, L., Appl. Magn. Reson., 2010, vol. 38, no. 2, p. 139.

34. Beni, A., Dei, A., Laschi, S., et al., Chem. Eur. J., 2008, vol. 14 , no. 6 , p. 1804.

35. Dei, A., Gatteschi, D., Sangregorio, C., and Sorace, L., Acc. Chem. Res., 2004, vol. 37, no. 11, p. 827.

36. Carbonera, C., Dei, A., Letard, J.-F., et al., Angew. Chem., Int. Ed. Engl., 2004, vol. 43, no. 24, p. 3136.

37. Schweinfurth, D., Rechkemmer, Y., Hohloch, S., et al., Chem. Eur. J., 2014, vol. 20, no. 12, p. 3475.

38. Starikova, A.A., Chegerev, M.G., Starikov, A.G., and Minkin, V.I., Comp. Theor. Chem., 2018, vol. 1124, p. 15.

39. Starikova, A.A., Metelitsa, E.A., and Minkin, V.I., Russ. J. Coord. Chem., 2019, vol. 45, no. 6, p. 411. https://doi.org/10.1134/S1070328419060095

40. Starikov, A.G., Chegerev, M.G., and Starikova, A.A., Struct. Chem., 2020, vol. 31, no. 1, p. 37.

41. Minkin, V.I., Starikova, A.A., Chegerev, M.G., and Starikov, A.G., Russ. J. Coord. Chem., 2020, vol. 46, no. 6 , p. 371.

https://doi.org/10.1134/S1070328420060068

42. Starikova, A.A., Chegerev, M.G., and Starikov, A.G., Chem. Phys. Lett., 2021, vol. 762, p. 138128.

43. Thuery, P. and Masci, B., Supramol. Chem., 2003, vol. 15 , no. 2 , p. 95.

44. Abrahams, B.F., FitzGerald, N.J., and Robson, R., Inorg. Chem., 2010, vol. 49, no. 13, p. 5953.

45. Loughrey, J.J., Sproules, S., McInnes, E.J.L., et al., Chem. Eur. J., 2014, vol. 20, no. 21, p. 6272.
46. Starikova, A.A., Starikov, A.G., and Minkin, V.I., Russ. J. Coord. Chem., 2017, vol. 43, no. 4, p. 197. https://doi.org/10.1134/S1070328417040066

47. Starikova, A.A. and Minkin, V.I., Russ. Chem. Rev., 2018, vol. 87, no. 11, p. 1049.

48. Frisch, M.J., Trucks, G.W., Schlegel, H.B., et al., Gaussian 16. Revision C. 01, Wallingford: Gaussian, 2016.

49. Tao, J.M., Perdew, J.P., Staroverov, V.N., and Scuseria, G.E., Phys. Rev. Lett., 2003, vol. 91, no. 14, p. 146401 .

50. Staroverov, V.N., Scuseria, G.E., Tao, J., and Perdew, J.P., J. Chem. Phys., 2003, vol. 119, no. 23, p. 12129.

51. Bannwarth, A., Schmidt, S.O., Peters, G., et al., Eur. J. Inorg. Chem., 2012, no. 16, p. 2776.

52. Cirera, J., Via-Nadal, M., and Ruiz, E., Inorg. Chem., 2018, vol. 57, no. 22, p. 14097.

53. Cirera, J. and Ruiz, E., J. Mater. Chem. C, 2015, vol. 3, no. 30 , p. 7954.

54. Minkin, V.I., Starikov, A.G., and Starikova, A.A., Pure Appl. Chem., 2018, vol. 90, no. 5, p. 811.

55. Piskunov, A.V., Pashanova, K.I., Ershova, I.V., et al., J. Mol. Struct., 2018, vol. 1165, p. 51.

56. Starikov, A.G., Starikova, A.A., Chegerev, M.G., and Minkin, V.I., Russ. J. Coord. Chem., 2019, vol. 45, no. 2 , p. 105.

https://doi.org/10.1134/S1070328419020088

57. Noodleman, L., J. Chem. Phys., 1981, vol. 74, no. 10, p. 5737.

58. Shoji, M., Koizumi, K., Kitagawa, Y., et al., Chem. Phys. Lett., 2006, vol. 432, nos. 1-3, p. 343.

59. Chemcraft, version 1.8, 2014:

http://www.chemcraftprog.com.

60. Pierpont, C.G., Coord. Chem. Rev., 2001, vol. 216, p. 99.

61. Tichnell, C.R., Shultz, D.A., Popescu, C.V., et al., Inorg. Chem., 2015, vol. 54, no. 9, p. 4466.

62. Simaan, A.J., Boillot, M.-L., Carrasco, R., et al., Chem.-Eur. J., 2005, vol. 11, no. 6, p. 1779.

63. Starikova, A.A., Chegerev, M.G., Starikov, A.G., and Minkin, V.I., J. Comput. Chem., 2019, vol. 40, no. 26, p. 2284.

64. Girerd, J.-J., Boillot, M.-L., Blain, G., and Rivière, E., Inorg. Chim. Acta, 2008, vol. 361, nos. 14-15, p. 4012.

65. Floquet, S., Simaan, A.J., Riviere, E., et al., Dalton Trans., 2005, no. 9, p. 1734.

Translated by E. Yablonskaya

Vol. $47 \quad$ No. $9 \quad 2021$ 